9. Light, J. S., and Hodes, H. L.: Studies on epidemic diarrhea of the new-born; isolation of a filtrable agent causing diarrhea in calves. Amer. J. Publ. Health, 33: 1451 (1943).

10. Light, J. S., and Hodes, H. L.: Isolation from cases of infantile diarrhea of a filtrable agent causing diarrhea in calves. J. Exp. Med., 90: 113 (1949).

11. Stair, E. L., Mebus, C. A., Twiehaus, M. J., and Underdahl, N. R.: Neonatal calf diarrhea. Electron microscopy of intestines infected with a reovirus-like agent. Vet. Pathol., 10: 155 (1973).

Copyright (c) 1976 International Pediatric Research Foundation, Inc.
12. Wyatt, R. G., Kapikian, A. Z., Thornhill, T. S., Sereno, M. M., Kim, H. W., and Chanock, R. M.: In vitro cultivation in human fetal intestinal organ culture of a reovirus-like agent associated with nonbacterial gastroenteritis in infants and children. J. Infect. Dis., 130: 523 (1974).

13. Requests for reprints should be addressed to: H. L. Hodes, M.D., Department of Pediatrics, Mount Sinai School of Medicine, 5th Ave. and 100th St., New York, N. Y. 10029 (USA).

14. Accepted for publication December 8, 1975.

Pediat. Res. 10: 204-205 (1976)

\title{
Presentation of the Howland Award to Harry H. Gordon
}

\author{
BARTON CHILDS ${ }^{(3)}$ \\ Department of Pediatrics, Johns Hopkins University School of Medicine, Baltimore, Maryland, USA
}

The Howland Award is intended to testify to the qualities of its recipient and to the significance of his contributions, and as such should be received by him as public evidence of the approbation of his colleagues. But it also has another purpose. In singling out one person, it focuses on one career as worthy of admiration and emulation; and it is, therefore, an important device of nonbiologic inheritance. That is, it is a means of reminding pediatricians of how much their own knowledge and attainments are based on those of the recipients of this award.

Today we honor Harry $H$. Gordon, native of New York; graduate in Medicine at Cornell; intern in Pathology at Montefiore Hospital; intern and resident in Pediatrics at Yale; member of the medical faculties of Cornell, University of Colorado, Johns Hopkins, and Einstein; Pediatrician-in-Chief of the Colorado General Hospital and the Sinai Hospital of Baltimore; recipient of the Borden Award; consultant to the National Institutes of Health, the National Research Council, and the National Association for Retarded Children; and past president of both pediatric research societies. That is the bare outline of his career, but it gives little information about him. Figure 1 is a recent photograph of Harry Gordon taken during his incarnation as Director of the Rose F. Kennedy Center for Research in Mental Retardation and Human Development at Einstein. Here is much more information. The pose is characteristic; leaning slightly forward, attentive ear at the ready, radiating welcome, he is looking across his desk at some supplicant; a medical student, a resident, a faculty colleague, the dean, the chairman of a search committee from some other school, it could be anyone. Each would receive a considerate hearing and each would be given advice, reassurance, a candid opinion, encouragement, or whatever other disinterested response might be appropriate, probably accompanied by an allusion to the wisdom of some ancient rabbi. Much of his time has been spent in this way. In Baltimore he was known generally as "everybody's psychiatrist," and his effectiveness in this role is witnessed by the legion of protegés and colleagues whose lives and careers he has influenced. Among Harry Gordon's most salient characteristics is his genuine respect and concern for people, including those who weigh only a few hundred grams, medical students, women, and members of other oppressed minorities.

There is much more information about Harry Gordon in the picture. Behind him, like a good citizen of old Rome, he has arranged his lares et penates, his tutelary gods, from whom, he would say, he has drawn inspiration, guidance, and encouragement. Most of them that I knew would protest that the exchange was bilateral, but notwithstanding, they are interesting in that they reflect accurately the attributes of Harry's character and the interests of his career. There are Oscar Schloss and Grover Powers, his teacher at Cornell and his chief at Yale, both of whom were exemplary clinicians to whom the heart of pediatrics lay in intimate and daily touch with patients, students, and house staff. There are John Benjamin, psychiatrist, and Alfred Washburn, proponent of the longitudinal study of human development, two, among other friends in Denver, who helped to engender and to incubate those ideas about human development which culminated in the center at Einstein. There is Ethel Dunham, whose broad experience of premature infants is summarized in her book which was written at Harry Gordon's urging. An enemy of bureaucratic sclerosis, Dr. Dunham, while at the Children's Bureau, appointed Harry Gordon a member of the Bureau staff so that his university salary could be devoted to his research on premature babies at Cornell. And there is Edwards Park, whose formidable scholarship and adamantine discipline were softened by a gentle and disarming humor. Roman emperors were sometimes deified and took their places on the walls of Roman houses. This one appears here no doubt because his support gave impetus to, and facilities for, the study of developing children.

This photograph is the Harry Gordon of the present. What of the past? Contributions which endure usually lose connection with their originators. J. B. S. Haldane drew attention to the point by saying that the discoveries of which he was most proud were those which had passed into the public lore, so that they were no longer given any citation in the literature, and their authorship was, therefore, lost to view. By that, of course, he was referring to their broad importance and universal acceptance. This is now happening to the painstakingly detailed and precise nutritional balance studies of Gordon, Levine, and others, upon which infant nutrition as we know it now is squarely based. These seminal papers recounted observations on the requirements of full term and premature infants for water, nitrogen, fat, calories, and other nutrients $(1,2)$. In all they exceed 20 in number and are not now commonly cited, but then, neither is Harvey's De Motu Cordis. According to these experiments, $120 \mathrm{cal} / \mathrm{kg} / \mathrm{day}$ was found to be, 
Fig. 1. Harry H. Gordon. Taken 1974. Photographs behind Dr. Gordon, beginning upper left and proceeding clockwise: Edwards A. Park, President John F. Kennedy, John Benjamin, Ethel C. Dunham, Oscar M. Schloss, Grover F. Powers, and Alfred H. Washburn.

on the average, an optimal intake for newborn infants, including premature babies. Later on Gordon tested these experimental conclusions in another way, putting the question more directly to the babies themselves by feeding them on demand. They did not disappoint him-much; they took on the average $119 \mathrm{cal} / \mathrm{kg} /$ day.

Of other research adventures; studies of malaria carried out during the war; hints of the role of oxygen in retrolental fibroplasia; the nutritional role of vitamin $E$, indeed of much else time is insufficient to tell. In Colorado, as Chairman of Pediatrics, he instituted a tradition for research and teaching in neonatology which persists undiminished, although he has been elsewhere for more than 20 years. It was also in Denver that his thoughts on the uses of diverse disciplines in the study of human development were first formulated. In Baltimore he raised a community hospital to the highest level of excellence in patient care, teaching, and research. It was his aim to make the Sinai Hospital the center for teaching in community medicine for the Hopkins Medical Institutions-and that, many years before "community medicine" became a cliché. But dreams, as we know, are made of fragile stuff-and that one more than most. At Einstein, despite a side-slip into the Dean's office, he has created the opportunity to give shape to a lifetime of thinking and planning, and has founded an institute to carry out that many sided study of mental retardation and development first contemplated more than 20 years before. In all of this he has never succumbed to the lure of frivolous goals; he has shunned glamor and self-importance.

Edward Gibbon said of an African bishop of the second century that he "had acquired a reputation for statesmanship without forfeiting that of a saint." Saint is perhaps too strong a word, even for Harry Gordon, but translated into modern terms, the characterization is an apposite one.

And so, Harry, I know that everyone here joins me in the great pleasure of presenting you this Howland award.

\section{REFERENCES AND NOTES}

1. Gordon, H. H.: Inconclusions of studies, mostly of premature infants. Pediatrics, 8: 163, (1951).

2. Gordon, H. H., and Levine, S. Z.: The metabolic basis for the individualized feeding of infants, premature and full-term. The Borden Award. J. Pediat., 25: 464, (1944).

3. Requests for reprints should be addressed to: B. Childs, M.D.. Department of Pediatrics, Johns Hopkins Hospital, Baltimore, Md. 21205 (USA).

4. Accepted for publication December 8, 1975. 